\title{
QUALITY OF LIFE AMONG PATIENTS WITH DEPRESSION
}

\author{
Sandra Matovic, Slobodan Jankovic \\ Department of Pharmacology and Toxicology, Faculty of Medical Sciences, University of Kragujevac, Kragujevac, Serbia

\section{KVALITET ŽIVOTA PACIJENATA SA DEPRESIJOM} \\ Sandra Matović, Slobodan Janković \\ Katedra za farmakologiju i toksikologiju, Fakultet medicinskih nauka, Univerzitet u Kragujevcu, Kragujevac, Srbija
}

\begin{abstract}
Depression is a disease of great social and medical importance. Quality of life can correlate with severity of manifested depression. The aim of our study was to determine whether people with unipolar depression have a poorer quality of life than healthy individuals, in what areas they have poorer quality of life and how socio-demographic characteristics and different therapies impact quality of life.

The survey was conducted among 110 subjects, of which 55 were patients diagnosed with depression using ICD-10 criteria at the Psychiatric Clinic in Kragujevac and 55 were healthy subjects. Quality of life was evaluated by The Quality of Life Questionnaire compiled by the WHO. Quality of life was compared between the two groups and within research groups, depending on the applied therapy.

There were statistically significant differences in quality of life between the groups: physical health -49.64 versus 70.84, $p=0.000$; psychological health -38.69 versus 69.85, $p=0.000$; social relations -53.73 versus $64.89, p=0.004$; living conditions -54.58 versus $66.7, p=0.000$, and in overall quality of life -75.41 versus $96.00, p=0.000$.

The results showed that there was no statistically signifcant difference in quality of life between applied therapies.

The overall quality of life of depressed patients did not depend on marital status or gender of the respondents.

Depressed patients generally have a low quality of life in all domains and in overall quality of life. To improve of mental health, oOne of the primary goals to improve mental health should be to improve quality of life among depressed patients.
\end{abstract}

Keywords: quality of life, depression, antidepressant therapy

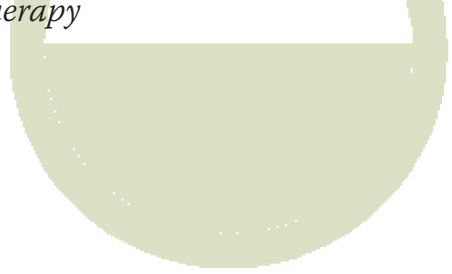

\section{SAŽETAK}

Depresija je bolest od velikog društvenog $i$ medicinskog značaja. Kvalitet života može biti u korelaciji sa težinom manifestovane depresije. Cilj našeg istraživanja bio je da se utvrdi da li osobe sa unipolarnom depresijom imaju lošiji kvalitet żivota u poređenju sa zdravim pojedinacima, u kojim oblastima, kao i kako određene socio-demografske karakteristike i različite terapije utiču na kvalitet života.

Istraživanje je sprovedeno medu 110 ispitanika: 55 pacijenata kojima je dijagnostikovana depresija korišćenjem ICD-10 kriterijuma na psihijatrijskoj klinici u Kragujevcu $i 55$ zdravih ispitanika. Kvalitet života je procenjen korišćenjem Upitnika o proceni kvaliteta života Svetske zdravstvene organizacije. Poređen je kvalitet života istraživačke $i$ kontrolne grupe, kao i u okviru istraživačke grupe, u zavisnosti od primenjene terapije.

Pokazano je da postoji statistički značajna razlika u kvalitetu života između grupa: fizičko zdravlje 49.64 prema 70,84, $p=0,000$; psihičko zdravlje-38.69 prema 69.85, $p=$ 0,000; društveni odnosi-53.73 prema 64,89, $p=0,004$; životni uslovi 54.58 prema 66,7, $p=0,000$, kao i ukupan kvalitet života-75.41 prema $96,00, p=0,000$.

Rezultati pokazuju da ne postoji statistički značajna razlika u kvalitetu života u zavisnosti od primenjene terapije.

Vrednosti ukupnog kvaliteta života depresivnih pacijenata ne zavise od bračnog statusa ili pola ispitanika.

Depresivni pacijenti imaju generalno niske vrednosti kvaliteta života u svim pojedinačnim domenima, kao i u ukupnom kvalitetu żivota. U ime unapredenja mentalnog zdravlja, jedan od primarnih ciljeva treba da bude poboljšanje kvaliteta života depresivnih pacijenata.

Ključne reči: kvalitet života, depresija, antidepresiva terapija

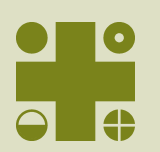




\section{INTRODUCTION}

Depression can occur as a symptom or syndrome in different psychiatric diseases or as an independent entity. The concept of depression involves a large number of clinical phenomena, such as feelings of sadness, hopelessness and helplessness, sleep disturbance, loss of appetite, decreased libido, and suicidal thoughts, that, depending on intensity and quality, determine whether a depressive disorder is present at the neurotic or psychotic level [1].

The World Health Organization defines quality of life as an individual's perception of their station in life in terms of the culture and value system in which they live, which is related to their goals, expectations, standards and concerns. This concept consists of physical health, psychological health, level of the independence, social relationships, beliefs and relationships with the environment [2].

According to the forecasts of experts, depression will be the most common cause of morbidity by 2030, indicating a growing need to invest effort in the prosperity and conservation of mental health [3].

The strategy for the development of mental health lists prevention and early diagnosis of mental disorders as one of the main goals [4].

The first requirement of an adequate therapeutic approach for a depressed patient is accurate diagnosis. All therapeutic strategies have the same goals: to reduce or eliminate symptoms, to increase the extent to which a subject "feels good", to increase quality of life, and to prevent recurrence of the disease, i.e., relapse. The main antidepressant drug groups, classified by their mechanism of action, are tricycle and similar antidepressants (TCA), selective serotonin reuptake inhibitors (SSRI), monoamine oxidase inhibitors (MAOI), and "atypical" antidepressants [5-7].

The aim of this study was to determine whether unipolar depression patients undergoing the appropriate therapy have a poorer quality of life that healthy people, in what areas they suffer a poorer quality of life, and how certain socio-demographic characteristics and different therapies have on impact quality of life of these patients.

\section{PATIENTS AND METHODS}

\section{Subjects}

This study was conducted in July 2011 at the Psychiatric Clinic in Kragujevac by interviewing respondents to assess their quality of life. This study included 110 patients; the research group consisted of 55 patients suffering from unipolar depression, and the control group consisted of 55 healthy subjects. The groups were matched by sex, place of residence, age and marital status.

The research group included patients of both sexes, with ages of 24-78 years, who were diagnosed with unipolar depression and, therefore, had previous ambulance or hospital treatment. Patients were included who fulfilled the ICD-10 criteriathe, were classified as having a major depressive episode (F32.0, F32.1 and F32.2) and recurrent depressive disorder (F33.0, F33.1 and F33.2) without psychotic elements and who had been using antidepressant drugs for at least three months were included in the study. They are divided into two groups; the first group was of patients taking selective serotonin reuptake inhibitors (SSRI), and the second group was of patients using drugs from other groups of antidepressants.

We tested whether selective serotonin reuptake inhibitors were more effective in improving the quality of life of the patients than other antidepressants.

\section{Statistics}

The required number of patients was calculated using a calculator and based on a t-test with $\alpha=0.05, \beta=0.5$ nd $R=0.8$. We found that the minimum total sample size was 102 , and the minimum number of participants per group was 51.

The two groups of patients were compared using the $x^{2}$ test. To obtain more valid results, it was essential that the two groups were as similar as possible. There were no statistically significant differences in socio-demographic characteristics between the two groups (all p values were $>0.05$ ) .

A general questionnaire about the patient's general socio-demographic and therapeutic data in addition to the World Health Organization Quality of Life-Brief (WHOQOL-BRIEF) scale, a short version of the WHOQOL-100, were used to obtain the necessary data. The WHOQOLBRIEF is a questionnaire that contains 26 questions to determine quality of life in four domains: (a) physical health (activities, need for treatment, amount of energy, mobility, presence of pain, sleep quality and capacity to work associated with health), (b) psychological well-being (satisfaction with self-body image, presence of negative emotions and positive emotions, self-esteem, religiosity, spirituality, learning, memory and concentration), (c) social relationships (personal relationships, social support, and sexual activity) and (d) living conditions (financial resources, a feeling of freedom, physical safety, social and medical security, home environment and physical environment including pollution, noise, traffic and air transport). The answer to each question was scored from 1 to 5 . Each domain is determined by the values of the relevant responses and then converted to new values using special tables [17].

Thus, it allows comparison between the domains and the WHOQOL-100 scale.

Data obtained from the scale for assessing quality of life were statistically analysed using SPSS 18 for Windows. A $\mathrm{X} 2$ test was used to compare certain quality of life variables between groups. The results were analysed using parametric t-tests and the nonparametric Mann-Whitney tests, depending on the presence of a normal distribution for each individual group. 
Table 1. Socio-demographic characteristics of the study subjects.

\begin{tabular}{|c|c|c|c|c|c|c|c|c|c|c|c|c|}
\hline & & Control & \multicolumn{7}{|c|}{ Research group } & \multirow[t]{3}{*}{$x^{2}$} & \multirow[t]{3}{*}{$\mathrm{p}$} & \multirow[t]{3}{*}{ d.f. } \\
\hline & & & \multicolumn{3}{|l|}{ SSRI } & \multicolumn{2}{|c|}{$\begin{array}{l}\text { Other } \\
\text { antidepressants }\end{array}$} & \multicolumn{2}{|c|}{ Summary } & & & \\
\hline & & No & Percentage & No & Percentage & No & Percentage & No & Percentage & & & \\
\hline \multirow{2}{*}{ Gender } & male & 19 & $35 \%$ & 13 & $38 \%$ & 6 & $29 \%$ & 19 & $35 \%$ & \multirow{2}{*}{0.000} & \multirow{2}{*}{1.000} & \multirow{2}{*}{1} \\
\hline & female & 36 & $65 \%$ & 21 & $62 \%$ & 15 & $71 \%$ & 36 & $65 \%$ & & & \\
\hline \multirow{6}{*}{ Age } & $20-29$ & 4 & $7 \%$ & 1 & $3 \%$ & 2 & $10 \%$ & 3 & $5 \%$ & \multirow{6}{*}{0.723} & \multirow{6}{*}{0.982} & \multirow{6}{*}{5} \\
\hline & $30-39$ & 4 & $7 \%$ & 3 & $9 \%$ & 2 & $10 \%$ & 5 & $9 \%$ & & & \\
\hline & $40-49$ & 5 & $9 \%$ & 4 & $12 \%$ & 3 & $14 \%$ & 7 & $13 \%$ & & & \\
\hline & $50-59$ & 26 & $48 \%$ & 17 & $49 \%$ & 9 & $42 \%$ & 26 & $47 \%$ & & & \\
\hline & $60-69$ & 9 & $16 \%$ & 5 & $15 \%$ & 3 & $14 \%$ & 8 & $15 \%$ & & & \\
\hline & $70-79$ & 7 & $13 \%$ & 4 & $12 \%$ & 2 & $10 \%$ & 6 & $11 \%$ & & & \\
\hline \multirow{2}{*}{$\begin{array}{l}\text { Marital } \\
\text { status }\end{array}$} & married & 43 & $78 \%$ & 24 & $71 \%$ & 15 & $71 \%$ & 34 & $76 \%$ & \multirow{2}{*}{0.431} & \multirow{2}{*}{0.511} & \multirow{2}{*}{1} \\
\hline & $\begin{array}{l}\text { Single/divorced/ } \\
\text { widowed }\end{array}$ & 12 & $22 \%$ & 10 & $29 \%$ & 6 & $29 \%$ & 11 & $24 \%$ & & & \\
\hline \multirow{2}{*}{$\begin{array}{l}\text { Place of } \\
\text { living }\end{array}$} & Urban place & 38 & $69 \%$ & 19 & $56 \%$ & 16 & $76 \%$ & 35 & $36 \%$ & \multirow{2}{*}{0.000} & \multirow[b]{2}{*}{1.000} & \multirow[b]{2}{*}{1} \\
\hline & Rural place & 17 & $31 \%$ & 15 & $44 \%$ & 5 & $24 \%$ & 20 & $64 \%$ & & & \\
\hline
\end{tabular}

d.f.- degrees of freedom; SSRI - selective serotonin reuptake inhibitors; $x 2$ - chi square test value

\section{RESULTS}

The frequencies and percentages of the socio-demographic characteristics of subjects and the values of $x^{2}$ tests between the research and control groups are shown in Table 1.
The subjects in the research group have used antidepressants from 3 months to 30 years.

Of the 55 patients, 34 (62\%) had used selective serotonin reuptake inhibitors, where 7 used paroxetine (20 $\mathrm{mg}), 22$ used sertraline $(50 \mathrm{mg})$ and 5 patients used citalopram (20 mg).

Table 2. Values from the WHOQOL-BRIEF scale, statistical parameters for domains and overall quality of life between depressed patients and healthy subjects.

\begin{tabular}{|c|c|c|c|c|c|c|c|c|c|c|}
\hline & $\begin{array}{l}\text { Physical } \\
\text { health } \\
\text { (mean) }\end{array}$ & s.d.. & $\begin{array}{l}\text { Psychological } \\
\text { health } \\
\text { (mean) }\end{array}$ & s.d. & $\begin{array}{l}\text { Social } \\
\text { relations } \\
\text { (mean) }\end{array}$ & s.d. & $\begin{array}{l}\text { Life } \\
\text { conditions } \\
\text { (mean) }\end{array}$ & s.d. & $\begin{array}{l}\text { General } \\
\text { quality of } \\
\text { life } \\
\text { (mean) }\end{array}$ & s.d. \\
\hline Research group-mean & 49.64 & 21.82 & 38.69 & 22.54 & 53.73 & 18.93 & 54.58 & 14.27 & 75.41 & 16.86 \\
\hline Control group-mean & 70.84 & 19.68 & 69.85 & 16.27 & 64.89 & 21.96 & 66.7 & 15.34 & 96.00 & 15.91 \\
\hline Mann Whitney-test value & \multicolumn{2}{|l|}{$-4,475$} & \multicolumn{2}{|l|}{-6.588} & \multicolumn{2}{|l|}{-2.885} & \multicolumn{2}{|l|}{-4.058} & \multicolumn{2}{|l|}{-5.777} \\
\hline$P$ value & \multicolumn{2}{|l|}{$0.000 * \%$} & \multicolumn{2}{|l|}{ 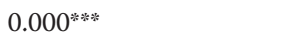 } & \multicolumn{2}{|l|}{$0.004^{* * *}$} & \multicolumn{2}{|l|}{$0.000^{* * * *}$} & \multicolumn{2}{|l|}{$0.000^{* * * * *}$} \\
\hline
\end{tabular}


Twenty-one subjects in the research group had used drugs from other groups of antidepressants, where 13 (15\%) had used venlafaxine (75mg, 150mg), 1 (2\%) used mianserin $(30 \mathrm{mg}), 2(4 \%)$ used trazodone $(150 \mathrm{mg})$ and 5 patients (11\%) used mirtazapine (15mg).

The physical health, psychological (mental) health, social relations and living conditions scores for the research group (depressed patients) and the control group (healthy subjects) are presented in Table 2.

Within the research group, the patients' quality of life was also analysed between the antidepressant therapies. In the research group, we tested whether the absence of a spouse further affected the quality of life.

\section{DISCUSSION}

There are several published studies with results similar to our findings. A study published in 1997 that compared quality of life between depressed patients and control subjects showed that depressed patients have generally lower scores and that scores do not depend on sex, age or other variables [8].

This study showed that patients with unipolar depression generally have poorer scores in all quality of life domains compared with the healthy population (Table 2).

The most significant predictors of depression in a study that used the SF 36 scale with 89 subjects were two items: the assessment of mental health and the assessment of general health [9].

In this study, we used the quality of life questionnaire issued by the World Health Organization. The lowest level of quality of life in depressed subjects from this study was in the domain of psychological well-being (38.69), although high statistical significance was also present in the areas of physical health, living conditions and overall quality of life. (Table 2)

The six-month study examined quality of life associated with health and the impact of antidepressants on quality of life [10].

This was a European observational study designed to assess the quality of life in 3468 adult patients with diagnosed episodes of depression before and after 3 or 6 weeks of treatment with antidepressants. In all groups of drug treatment, the greatest improvements occurred after 3 months of therapy. Another study dealt with the assessment of changes in depressive symptoms and monitoring quality of life during treatment with antidepressants [11].

Eighty-seven patients were followed in that study during hospitalization and after hospital discharge. The researchers also used the World Health Organization Quality of Life scale. The results showed that there was an increase in quality of life and reduction of symptoms during therapy. However, more than half of the patients had 10 or more symptoms at discharge.

Because our study was a cross-sectional design, the improvement of quality of life after administered therapy could not be shown. Another limiting factor of our study was that most of the patients were not hospitalized therefore adherence to therapy could not be assessed.

Other limiting factors were a small sample size and usage of other drugs in addition to antidepressants that could affect quality of life.

Comparing the patient groups, there were no statistically significant differences in single domains or in overall quality of life between patients taking SSRIs and patients taking other antidepressants.

Other studies with depressed patients have shown that approximately $60 \%$ of the cases of depression were not receiving treatment for depression [12]. This is supported by a cohort study that was performed on patients with major depression for a period exceeding 9 months [13]. One hundred seventy-nine patients (mostly women, $73 \%$ ), with an average age of 38 years were followed in that study. After 9 months, $42 \%$ of the patients still suffered from depression and $25 \%$ had complete remission, while only $9 \%$ were correctly treated with antidepressants. There was a statistically significant relationship at the beginning and after 9 months in terms of quality of life. This research showed poor quality of life among depressed patients, which suggests an inappropriate treatment of depression.

Although our study showed that quality of life was not affected by the type of antidepressant used, we did not compare quality of life between untreated depressive patients and those with antidepressants, which also could be a limitation of this study. A study that was conducted among 982 patients who did not use any antidepressants showed that quality of life is initially connected with depressive symptoms [14]. The primary care patients were followed at baseline and after 6 weeks, 3 months and 9 months. Patients who were diagnosed with depressive symptoms at baseline showed no improvement in any of the measures after nine months.

Our study included patients who were mostly female (65\%), and $72 \%$ of the control patients were more than 50 years old; however, the results were not related to the patient's age. A study that dealt with the correlation between age, depressive symptoms and quality of life was conducted on 443 adults over 30 years of age [15]. Depression was negatively associated with quality of life in the psychological and social domains, but age was not.

The study also showed that environmental quality of life increased with age, whereas physical quality of life decreased.

Lots of studies have dealt with pain, depressive symptoms and quality of life. A study that was performed with premenopausal women examined quality of life and pain in women who were diagnosed with unipolar depression [16]. The results showed that premenopausal women experienced pain and had lower quality of life than controls, especially in the domains of emotional status and social well-being. 
Another study that used a regression model was conducted among depressed women over 40 years of age and showed that both physical condition and severity of depression significantly influenced quality of life [17]. The intensity of depressive symptoms has been shown as the most important factor influencing quality of life. We can make the assumption that this study also demonstrates that depressive symptoms have great influence on quality of life. In our study, we did not analyse the effects of comorbidities, and the presence of other illness, especially of those associated with pain, can also affect quality of life.

A study that compared depressive symptoms and quality of life among patients with amyotrophic lateral sclerosis with the presence of pain dealt with that issue [18]. The results showed that depression scores significantly decreased quality of life, and that the effect remained significant after considering pain intensity as a covariate $(\mathrm{p}<0.05)$.

ALS patients with pain had lower quality of life and higher depressive symptoms than ALS patient without pain, but there was no significant difference between these two groups.

Our study compared quality of life between patients with unipolar depression that were treated in the Psychiatric Clinic in Kragujevac and healthy controls. A similar method was used and similar results were found in a study that was conducted among students in Turkey where the prevalence of depression was $21.8 \%$ [19]. Quality of life was lower in all domains among the students with depression compared to the students without depression. In terms of health-related quality of life, the students that presented with higher intensity of depressive symptoms obtained scores significantly lower in all domains and in general health-related quality of life in particular [20].

In a study that used a multilevel regression model, the presence of depressive symptoms in women was associated with poorer physical health related to quality of life, whereas depressive symptoms in men were associated with a decrease in mental health-related quality of life [21].

That study also showed that sex was not associated with quality of life, and quality of life was not different among students with and without an emotional partner.

\section{CONCLUSION}

A review of the literature revealed that unipolar depression leads to impairment in the quality of life in all areas. Our study has shown that patients with unipolar depression have a poorer quality of life than healthy individuals, especially in the domain of mental health. Selective serotonin reuptake inhibitors therapy was not more effective at improving quality of life in comparison with other antidepressants. The modern concept of protection and improvement of mental health defines the quality of life of mentally ill persons as one of primary goals, and this study supports that conclusion.

\section{REFERENCES}

1. Timotijevic I. Depression: clinical features and etiopathogenesis. Arh.farm Belgrade 2007, 57: 61-69.

2. Stankovic B, Nikolic-Balkoski G, Leposavić Lj, Popovic $\mathrm{Lj}$. Perception of quality of life and social adjustment of patients with recurrent depression. Biblid Belgrade 2006, 9-10: 369-374.

3. Kurian BT, Grannemann B, Trivedi MH. Feasible evidence-based strategies to manage depression in primary care. Curr Psychiatry Rep. 2012 Aug;14(4):370-5.

4. Miletic V, Marotic V, Pejovic-Milovancevic M, Perunicic I. Depression and chronic somatic diseases, Belgrade. Psihijat.dan. 2009, 41: 55-64.

5. Jankovic SM, Prostran M, Todorovic Z. Pharmacology and toxicology. Kragujevac and Belgrade 2007, 4: 102-104.

6. Rang HP, Dale MM, Ritter JM, Flower RJ. Pharmacology. 5th ed. 2005: 475-476.

7. Varagic VM, Milosevic MP. Pharmacology. 18th ed., Elit Medica, Belgrade, 2003: 115-122.

8. Pyne JM, Patterson TL, Kaplan RM et al. Assessment of the Quality of Life of Patients With Major Depression. Psychiatric services 1997; 48: 224-230.

9. Pavlovic A, Stojanovic M, Nikolic-Pejovic S, Maric N. Quality of life and severity of depression-scale analysis of the individual SF-36 and Cung self-assessment scale for depression. Engrami 2007, 29: 3-4.

10. Reed C, Monz BU, Perahia D. Quality of life outcomes among patients with depression after 6 months of starting treatment. Journal of Affective Disorders 113, 2009: 296- 302.

11. Gostautas A, Pranckeviciene A, Matoniene V. Changes in depression and quality of life during inpatient treatment of depression. Medicina (Kaunas) 2006; 42(6): 472-478.

12. McQuaid JR, Stein MB, Laffaye C, McCahill ME. Depression in a primary care clinic: the prevalence and impact of an unrecognized disorder. J Affect Disord.1999;55(1):1-10.

13. Lima A, Fleck M. Quality of life, diagnosis, and treatment of patients with major depression: a prospective cohort study in primary care. Revista Brasileira de Psiquiatria 2010: 33(3); 246-251.

14. Diehr PH, Derleth AM, McKenna SP et al. Synchrony of change in depressive symptoms, health status, and quality of life in persons with clinical depression Health and Quality of Life Outcomes 2006, 4:27; 1-10.

15. Brown PJ, Roose SP. Age and anxiety and depressive symptoms: The effect on domains of quality of life. Int J Geriatr Psychiatry. 2011; 26(12); 1260-1266.

16. Hartman JM, Berger A, Baker K et al. Quality of life and pain in premenopausal women with major depressive disorder: The power study. Health and Quality of Life Outcomes 2006, 4:2; 1-8.

17. Iglesias-García C, Prieto R. Quality of life in depressed women over 40 years old. Actas Esp Psiquiatr 2012; 40(4); 221-227. 
18. Pizzimenti A, Aragona M, Onesti E, Inghilleri M. Depression, pain and quality of life in patients with amyotrophic lateral sclerosis: a cross-sectional study. Functional Neurology 2013; 28(2): 115-119.

19. Arslan G, Ayranci U, Unsal A, Arslantas D. Prevalence of depression, its correlates among students, and its effect on health-related quality of life in a Turkish university. Upsala Journal of Medical Sciences. 2009; 114: 170-177.
20. Souza I, Paro H, Morales R et al. Health-related quality of life and depressive symptoms in undergraduate nursing students. Rev. Latino-Am. Enfermagem 2012; 20(4): 736-743.

21. Nan H, Lee P, Ni M, Chan B, Lam T. Effects of Depressive Symptoms and Family Satisfaction on Health Related Quality of Life: The Hong Kong family Study. PLoS one 2013; 8(3): 1-10. 